\title{
Sosyal Kaynak Belleği: Sosyal Etkileşimde Bulunduğumuz Kişileri Nasıl Hatırlıyoruz?
}

\section{Social Source Memory: How Do We Remember the People We Have Social Interaction with?}

\author{
Pınar Bürhan Çavuşoğlu 1 id
}

\section{öz}

Kaynak belleği, bir bilgiyi diğer bilgilerden farklılaştıran, 0 bilginin daha çok bağlamsal özelliklerinin saklandığı bir bellek türüdür. Sosyal hayatın bir parçası olan sosyal etkileşimlerden elde ettiğimiz bilgilerin kaynak belleği üzerindeki etkisi son zamanlarda araştırmacıların ilgisini çekmektedir. Bu çalışmanın amacı sosyal kaynak belleğinin temel mekanizmalarını açıklamaya yönelik olan çalışmaları derlemektir. Bu derlemenin illk bölümünde sosyal etkileşim ilgili öne sürülen varsayımlar özetlenmiştir. Sonraki iki bölümde sırasılya davranış detayları verilen yüzlerin ve sosyal işbirliği oyunundan (tutsak ikileminden) elde edilen sosyal bilginin kaynak belleği performansını nasıl etkilediği incelenmiştir. Sosyal bilgiye ilişkin kaynağın izlenmesi sürecinde negatif bilgiye daha çok eğilim gösterildiği görünmektedir. Ancak bu basit bir açıklama olacaktır. Genel olarak, kaynak belleği kategorik bir hatıllama sürecini gösteriyor gibi görünmektedir. Kaynak belleğinin bütün detayları bilinen bir hatırlama sürecine işaret etmemesi bellek yanlılıklarına sebep olmaktadır. Bellek bilgisinin zayıf olduğu durumlarda bilginin kaynağııı takip edebilmek zorlaşır. Bu gibi bir durumda bilginin kaynağını atfederken daha çok kişinin sahip olduğu şemalar, inançlar, beklentiler veya kalıp yargılar etkili olur. Bu sebeple kaynak belleği yanlılıklarını araştırmak yanlış bilgi atfinı önlemek için önemlidir. Kaynak belleğinin temel işleyiş mekanizmasını anlamak özellikle görgü tanıkığı konusuna ışık tutacaktır.

Anahtar sözcükler: Bellek, kişilerarass ilişkiler, sosyal etkileşim, yanlıık

\section{Abstract}

Source memory is a type of memory that differentiates information from other information, where more contextual properties of that information are stored. Recently, researchers have shown increased attention in the effect of the information obtained from social interactions, which are a part of social life, on source memory. This paper aims to review recent researches into the underlying mechanisms of social source memory. In the first part of this review summarized the assumptions put forward about social interactions. In the next two chapters, the faces of which the behavior details are given and the social information obtained from the social cooperation game (or the prisoner's dilemma) are viewed in terms of how they affect source memory performance. There seems to be a greater tendency towards negative information in the process of monitoring the source of social information. However, it would be a simple explanation. In general, source memory seems to be a categorical remembering process. The fact that the source memory does not point to a remembering process with all the details known causes memory biases. When memory is weak, it becomes difficult to trace the source of information. In such a case, the schemas, beliefs, expectations, or stereotypes are mostly effective in referring to the source of information. For this reason, it is essential to consider source memory biases in order to prevent false information. Understanding the underlying mechanism of source memory will shed light on eyewitnesses, mainly.

Keywords: Memory, interpersonal relations, social interaction, bias

\footnotetext{
1 Süleyman Demirel Üniversitesi, Isparta

$\checkmark$ Pınar Bürhan Çavuşoğlu, Süleyman Demirel Üniversitesi Fen Edebiyat Fakültesi Psikoloji Bölümü, Isparta, Turkey pinar.burhan@hotmail.com

Geliş tarihi/Received: 18.01 .2020 | Kabul tarihi/Accepted: 05.03.2020 |Çevrimiçi yayın/Published online: 03.05.2020
} 
BİR BİLGIYI, o bilgiyi edindiğimiz durum ya da olay ile nitelendirmek kaynak izleme (source monitoring) olarak adlandırilır (Johnson ve ark. 1993, Mitchell ve Johnson 2009). Mitchell ve Johnson (2009) karmaşık anılarımızın birbirinden farklı özellikler içerdiğini ve belli bir süre sonra yeniden hatırlandığında bu farklı özelliklerin zihinsel deneyimin kaynağı hakkında eşsiz bilgiler sunduğunu vurgulamaktadır. Bu özellikler o anıyı diğer anılardan farklılaştıran algısal, zamansal, mekânsal, anlamsal ve duygusal bilgileri içermektedir. Kaynak belleği, epizodik anıların niteliksel özelliklerinin hatıllanmasıdır (Mitchell ve Johnson 2009). İçerik (item memory) ve kaynak belleği (source memory) epizodik belleği oluşturur. İçerik belleği bir bilgi parçasını ifade ederken, kaynak belleği de o bilgi parçasının nereden, nasıl, kim tarafından, ne zaman elde edildiği ya da algısal özelliklerinin ne olduğuyla ilgili soruların cevabını içerir. Kaynak belleği bir başka deyişle, bir bilgiyi diğerlerinden farklı kılan o bilginin daha çok bağlamsal özelliklerinin saklandığı bir bellek türüdür. Kaynak belleği sunulan bilginin ne olduğundan ziyade hangi bağlamda sunulduğunun hatırlanmasıdır. Kaynağı izleme mekanizması da bu gibi bağlama ilişkin detayların geri getirilmesini içermektedir (Johnson ve ark. 1993, Mitchell ve Johnson 2009).

Gerçeği izleme modelinin (reality monitoring) bir uzantısı olarak Johnson ve arkadaşları (1993) tarafından sunulan kaynak izleme modeline göre, üç tip kaynak izleme biçimi vardır. Bunlar dışsal kaynağı izleme (external source monitoring), içsel kaynağı izleme (internal source monitoring) ve gerçeklik kaynağını izlemedir (reality source monitoring). Dışsal kaynağı izleme, dışsal olarak ortaya çıkan kaynakları birbirinden ayırt etmeyken (örn. Bu haberi veren A mıydı B miydi?); içsel kaynağı izleme, içsel olarak ortaya çıkan kaynakları birbirinden ayır etmedir (örn. A'nın bu haberi verdiğini düşünme ve bu düşünceyi söylemiş olmayı birbirinden ayırt etme). Gerçeklik kaynağını izleme aynı zamanda içsel-dışsal gerçekliği izleme (internal-external reality monitoring) olarak da bilinmektedir. Gerçeklik kaynağını izleme, kaynağın içsel olarak mı yoksa dışsal olarak mı ortaya çıktığını ayırt etmedir (örn. A'nın bu haberi gerçek hayatta söylemesiyle onun bu haberi sanal olarak paylaşmasını ayırt etme).

Johnson ve arkadaşları (1993) belleğin yapılanmasında algısal, bağlamsal, anlamsal ve duygusal bilgilerin kayıt edilmesi ve bunların geri getirilmesi için gerekli bilişsel süreçlerin kaynak izleme biçimini etkilediğini belirtir. Kaynağın saptanabilmesi için diğer bilişsel süreçlerle beraber bellekte kayıt edilmiş bilgilerin aktif hale getirilmesi gerekir. Sonrasında karar verme süreçleri bu işleme dâhil olur ve var olan bilgiler bir kaynağa atfedilerek kaynak saptanabilir. Ancak kaynağın doğru izlenemediği durumlarda sahte hatırlamalar da ortaya çıkabilmektedir (Schacter 1999, Gallo 2010). Bu sebeple kaynak izleme üzerinde hangi faktörlerin etkili olduğunu araştırmak önemlidir.

Kaynak izlemeyi ölçmek için kullanılan pek çok yöntem vardır. Bazı deneylerde kaynağı tespit etmek amacıyla "kelimeyi hangi listede görmüştünüz? A mı? B mi?” gibi açıkça sorulabildiği gibi, Mitchell ve Johnson (2009)'in derlemesinde yer verdiği ve diğer çalı̧smalarda da sıklıkla kullanılan aşağıdaki yöntemlerle de ölçülebilmektedir:

Hatırlama/bilme (remember/know); bağlam, ilişkisel ya da çağrışımsal bellek testleri; bellek ilişkilendirme görevleri (memory binding tasks); dahil etme/dışlama görevleri (inclusion/exclusion tasks); kriterlere dayalı hatırlama görevleri (criterial recollection tasks); liste ayırt etme; kriptomnezi (bilinçsiz aşırma) görevi; anlamsal olarak ilişkili olan sunulan ve sunulmayan içerikleri ayırt etme (DRM paradigması) ve benzerleri (Mitchell ve Johnson 2009). 
Kaynak belleği farklı tip kaynak bilgilerinden (mekânsal, zamansal, algisal ya da duygusal gibi) oluşabilmektedir. Bu farklı tip kaynak bilgileri mediyal temporal lobta farklı alanlarda karşılık bulmaktadır (Peters ve ark. 2007). Bunun yanında uyaranın materyaline bağl1 olarak kaynak belleğiyle ilişkili nöral aktivite de kısmen değişebilmektedir (Duarte ve ark. 2011). Bu durum kaynak belleğinin, bilginin farklı özelliklerine (algısal, zamansal, mekânsal, anlamsal ya da duygusal özelliklerine) göre farklı bilişsel süreçlere işaret edebileceğinin göstergesi olabilir. Bu sebeple kaynak belleğinin temel bilişsel mekanizmasını incelerken bilginin farklı özelliklerini dikkate almak gerekebilir.

Mitchell ve Johnson (2000) benzeri bir düşünüşle, hatırlama aşamasında kaynağ1 atfederken iki temel bilgi kategorisinden faydalandığımızı söylemektedir. Bunlardan ilki bilginin algısal ve bağlamsal özellikleri gibi nitel özellikleridir. Bu sürecin daha hızlı ve otomatik olduğuna değinilmektedir. Bunlardan ikincisi de daha sosyal olarak şemalar, inançlar ve genel bilgilerin yer aldığı kavramsal bilgilerdir. Bu tip bir sürecin ise daha yavaş ve kontrollü olduğuna değinilmiştir. Benzeri bir şekilde, Johnson ve arkadaşları (1993) da kaynak izlemenin ya da kaynağı atfetmenin kimi zaman farkında olmadan hızlı ve kısmen de olsa bilinçdışı olduğunu; kimi zaman da daha yavaş ve üzerinde düşünmüş bir şekilde daha analitik ve daha kontrollü olduğunu söylemektedir. Kaynak belleğinin, farklı bilgi kategorilerinden faydalanması, farklı bilişsel süreçlere işaret edebileceğini düşündürmektedir. Bu sebeple, bu derlemenin konusu, sadece sosyal bilgilere ilişkin kaynak belleğinin temel bilişsel mekanizmasını anlamaya yönelik olacaktır.

Alan yazında kaynak belleğini ölçmeyi amaçlayan çalışmalarda sadece kullanılan bilgi türünde farklılıklar görülmemektedir, aynı zamanda deney yöntemlerinde de farklılıklar görülmektedir (Mitchell ve Johnson 2009). Bilişsel psikoloji alanında çalışan araştırmac1lar uzunca bir zamandır kaynak belleğinin temel bilişsel mekanizmaları üzerine çalışmaktadır. Bu çalışmaların genel amacı kaynak belleğinin genel ilkelerini gün yüzüne kavuşturmaktır (derleme için bknz. Johnson 1997). Bu çalışmalar büyük ölçüde kaynak belleğinin temel bilişsel yapılarını anlamamız için önemli katkılar sağlamıştır. Ancak çalışmaların çoğunda yapay materyaller kullanılarak kaynak belleğiyle ilgili sorulara cevap aranmıştır. Bu durum evrimsel psikologların da sıklıkla eleştirdiği konular arasındadır. Evrimsel psikologlara göre kelimenin renginin neden hatırlanması gerektiğinin işlevsel bir cevabı olmalıdır (Nairne ve Pandeirada 2008). Örneğin Doerksen ve Shimamura (2001)'nın çalışmasında uyaran olarak kelimeler (Deney 1 ve 2: hoşa giden, hoşa gitmeyen ve nötr kelimeler) ve hatırlanması istenen bağlam bilgisi olarak da kelimelerin rengi (Deney1: sarı ya da mavi) ya da sunuldukları çerçevelerin renkleri (Deney2: sarı ya da mavi) sorulmuştur. Test aşamasında önce serbest hatırlama yapılmış ve daha sonra kaynak hatırlama testi verilmiştir. Kaynak belleği testinde katılımcılardan, ekranda siyah renkte görünen kelimelerin çalışma aşamasında sunulup sunulmadığı, sunulduysa hangi renkte ya da hangi çerçeve renginde sunulduğunun hatırlanması istenmiştir. Bu ve buna benzer pek çok çalı̧̧ma, kaynak belleğinin bilişsel işleyişi hakkında oldukça önemli bilgiler vermektedir. Ancak bir kelimenin renginin ya da sunulduğu çerçevenin ne olduğunu hatırlamak günlük hayatta çok nadiren karşılaşacağımız bir durumdur. Literatürde bu yapay görevlerin dışında sosyal hayatta karşılaşma olasılığımızın daha yüksek olduğu ve sosyal bilgilerin sunulduğu deneyler de bulunmaktadır (Bell ve ark. 2012a, 2012b). Örneğin hiç tanımadığımız bir kişiyle ilgili onun davranışlarını tanımlayan bilgiler (örn. sınavlarda kopya çeker) öğrenebilir ve sonrasında bu kişiyle olası ilişkilerimizi düzenlemek için bu davranışları doğru hatırlamamız gerekebilir. Sosyal bir bilginin sunulduğu ve bu bilgiye ilişkin kaynak belleği performansının nasıl değiştiğini inceleyen çalışmaların 
bulgularını derlemek, kaynak belleğinin temel bilişsel mekanizmasına yönelik anlayışımıza katkı sağlayacaktır.

$\mathrm{Bu}$ derlemenin temel amacı, sosyal etkileşimlerden edindiğimiz sosyal bir bilgi için kaynak belleği performansının ne yönde değiştiğini incelemektir. Bir başka deyişle, bu derlemede sosyal kaynak belleğini etkileyen faktörlerin neler olduğu incelenecektir. Derlemenin amacıyla ilişkili, Aralık 2019 tarihine kadar olan ve son 15 yıldaki görgül/deneysel çalışmalara ve literatür derlemelerine "PubMed, PsycInfo, Web of Science ve Google Scholar” elektronik veri tabanları aracılığıyla ulaşılmıştır. Taramalar İngilizce ve Türkçe dilinde yazılmış ampirik araştırmalara yönelik olmuştur. Derlemede üç ana başlık yer almaktadır. İlk başlıkta kavramsal bir arka plan sağlamak amacıyla sosyal etkileşim ve sosyal işbirliğini açıklamaya yönelik alan yazında yer alan varsayımlar incelenmiştir. İkinci başlıkta, davranış detayları verilen kişiler için kaynak belleği performansının hangi faktörlerden etkilendiği incelenmiştir. Bu başlık altında incelenen araştırmalarda, daha önce karşılaşılmamış bir kişiyle ilgili o kişinin nasıl bir davranış sergilediği bir cümle ile açıklanmaktadır. Yüzler olumlu, olumsuz ya da kalıp yargısal davranış tanımlamalarıyla eşleştirilmiştir. Sonrasında katılımcılardan o kişiyi tanıması ve davranışının ne olduğunu hatırlaması istenir. Üçüncü başlıkta, kişiler hakkında oyundan elde edilen olumlu ya da olumsuz deneyime bağlı olarak kaynak belleği performansının nasıl değiştiği incelenmiştir.

\section{Sosyal etkileşim ve sosyal işbirliği}

Blau (1968) alan yazında ilk kez sosyal takasın/sosyal alışverişin (social exchange) temel özelliklerini ayrıntılarıyla açıklamıştır. Bu açıklamasına göre insanların diğerleriyle kuracakları etkileşimden sağladıkları ödüle göre sosyal ilişkilerini düzenlediklerini ve bu ödüller için etkileşimi sürdürdüklerini söylemektedir. Öne sürdüğü sosyal takas teorisiyle insanların sosyal ilişkilerinde diğerlerinden sağladıkları faydaya odaklandıkları vurgulanmaktadır. Bunun yanında bu karşılıklı ilişkilerin (reciprocity) bir ahlaki temele dayanmas1 gerektiğini düşünmektedir. Bireyler açık ya da örtük olarak bir sosyal sözleşmeye (social contract) bağlı kalacaklarını kabul ederler (Cosmides ve Tooby 2015). Örneğin bir kişi diğer bir kişi ile olan etkileşiminden fayda sağladıysa, o kişiye fayda göstermekle sorumlu olmalıdır. Tam tersine yardım ettiğimiz kişiler de bunu geri ödemekle yükümlü olmalıdır. Sosyal takas örtük ya da açık, eş zamanlı ya da sırayla, hemen ya da ertelemeli olabilir (Cosmides ve Tooby 2015). Bir başka değişle sosyal takas, iki taraf arasında değişebilen ya da daha karmaşık yapıları takip eden eylemleri içerebilen, karşılıklı fayda için işbirliği yapmaktır (Tooby ve Cosmides 1996, Cosmides ve Tooby 2015).

Evrimsel bir bakış açısıyla bakacak olursak, sınırlı kaynakların bulunduğu bir dünyada yaşayan insanlar, bu sınırlı kaynaklar için devamlı yarış halindedir. Ancak bu durum sosyal ilişkilerle örülü bir ortamda yaşayan bizler için bazı ikilemleri de beraberinde getirmektedir. Bireyler sosyal bir etkileşim esnasında farklı sonuçlar doğuracak eylemlerinden hangisini seçecekleri konusunda bazen ikilemlere düşebilmektedir. Çalışmalarda da sıklıkla kullanılan Tutsak İkilemi (Prisoner's Dilemma) bu durumun en güzel örneğidir. Senaryoya göre iki zanlı bir soruşturma kapsamında ayrı hücrede tutularak sorguya alınmıştır. Her iki zanlı da sessiz kalırsa ve suçu itiraf etmezse, tutuklama için yeterli delil olmadığından en az cezayı alacaklardır. Ancak zanlılardan biri, cezadan muaf olmak için suçu itiraf ederse, itiraf eden serbest bırakılırken diğer zanlı ağır ceza alacaktır. Her iki zanlı da itiraf ederse, her ikisi de ağır ceza alacaktır. Diğer kişinin ne yönde bir karar 
vereceğini bilmenin imkânsız olduğu durumlarda, ne yapacağına karar vermek büyük ölçüde bir ikilem yaratmaktadır. Bu durumda ve benzeri diğer durumlarda işbirliği yapmak çoğu zaman riskli bir tercih olacaktır. Buna rağmen çoğu zaman işbirliği yapmayı tercih edebiliyoruz.

İşbirliğinin toplumlarda nasıl ortaya çıktığıyla ilgili bazı teoriler öne sürülmektedir. Bunlardan biri Hamilton'un (1964) öne sürdüğü kapsamlı seçilim değeridir (inclusive fitness). Bu teoriye göre işbirliği davranışı her ne kadar işbirliği yapan kişi için zararlı olsa da, kişisel çıkarlarla ilişkili olan bireylere fayda getirdiğinden yok olmamış bir davranıştır. Hamilton'un bu teoride bahsettiği kişisel çıkarlarla ilişkili bireyler akrabalarımızdır. Ancak akrabalarımız dışındaki bireylerle de, örneğin ortaklarımız ya da arkadaşlarımızla da işbirliği yapmaktayız. Trivers (1971) karş1lıklı özgecilik teorisinde (reciprocal alturism theory) işbirliği davranışının akrabalık bağının olmadığı bireyler için de evrildiğini öne sürmüştür. Bu teoriye göre yardıma ihtiyacı olan bir kişiye yardım etmek, sonrasında o kişi benzeri şeyi ona yardım eden kişi için de yapacaksa sürdürülür. Yardımlaşma konusunda karşılıklı ilişkinin sürdürülüp sürdürülemeyeceği tamamen belirsizdir. Herhangi bir fedakarlık göstermeksizin sadece fayda sağlamaya yönelik bir tutum sergileyen bir kişiye yardım etmek, herhangi bir karşılık göremeyen bireyin o kişiye yönelik sonraki yardım etme davranışını etkileyecektir.

Axelrod'un (1984) bilgisayar üzerinde oluşturduğu yarışma simülasyonu, karşılıklı yardımlaşma ve hilekârları tespit etme stratejilerini yürütmeye güzel bir örnek teşkil etmektedir. Bu oyunu kazanmak için "kısasa kısas (tit-for-tat)" stratejisini uygulamak gerekmektedir. Bu oyunda, oyuncu hilekâr ya da işbirlikçi ortaklarla karşılaşabilir. Oyuncudan beklenen bir sonraki hamlesini, ortağının davranışına göre düzenlemesidir. Bir başka deyişle, eğer oyuncu işbirlikçi bir ortak ile karşılaşmışsa bir sonraki karşılaşmasında işbirlikçi davranarak kazancını daha çok arttırması beklenir. Kısasa kısas oldukça basit bir strateji gibi görünmekle beraber sosyal ikilemleri çözmek için başarılı bir strateji olabilir.

Insanlar sadece akraba, dost ya da iş amacıyla bir araya geldikleri kişilere yardım etmez. Doğrudan karşılıklı ilişki kurmak her zaman mümkün olmayabilir. Dolaylı karşılıklilık teorisi (indirect reciprocity theory, Nowak ve Sigmund 2005) yardımın her zaman doğrudan olamayabileceği üzerinde durmaktadır. Bu teoriye göre insanların kazandıkları itibar yardım alma davranışını etkilemektedir. Bir başka deyişle, insanlar diğer kişilere yardım ettiklerinde iyi bir itibara sahip olurlar ve bu durum yardıma ihtiyacı oldukları zaman yardım alma olasılıklarını arttıracaktır. Tam tersine, insanlara yardım etmeyi reddeden bir kişi kötü bir itibara sahip olacaktır ve sonrasına bu durum onun yardım alma olasılığını düşürecektir. Bu teori ile yakın olarak maliyetli işaret yaklaşımı (costly signaling perspective) da birbirine karşl1ıklı destek olmanın o kişinin itibarına faydası olan bir işaret olduğunu varsaymaktadır.

İnsanlar bir arada yaşayan canlılar olduğundan çoğu zaman işbirliği içerisinde olmanın yaşamsal önemi olduğu söylenebilir. Bireylerarasındaki işbirliği yarar gören taraf için bazen yaşamsal olabilecek katkılar sağlayabilir ve hatta sonra bu ilişki karşıllklı olarak her iki taraf için de fayda sağlayabilecek hale dönüşebilir. Bir taraf diğerine, ileride onun da fayda göstereceğini bekleyerek yardım eder ve sonrasında diğer taraf da karş1lık gösterirse, her iki taraf da kazanır ve bu ilişki sürdürülür. Ancak bu ilişki taraflardan birinin hilekâr ya da bedavacı olmasıyla bozulabilir. Cosmides ve Tobby’e göre (1992) karşılıklı ilişkilerde hilekâr kişileri hatırlamak önemlidir. Bunun için doğru ve iyi bir hatırlama gereklidir. Bireylerarası ilişkinin devamlı fayda getirebilmesi için hilekârlardan uzak durmak ve iyi bir hilekârı tespit etme (cheater detection) stratejisi yürütmeyi gerektirir. 
Cosmides ve Tooby (2015) hilekârları, sosyal sözleşme ile belirtilen faydayı kabul eden ancak bu faydanın sağlanması koşulunun gerekliliklerini yerine getirmeyen ve karşılıklı ilişkiyi reddeden kişiler olarak tanımlamaktadır. Bir başka deyişle hilekâr kişiler, sosyal sözleşmeyi kasıtlı olarak ihlal eden kişilerdir. İşbirliğinde hilekâr kişileri diğer kişilerden ayırt edebilmek, fayda sağlamayı sürdürmemize yardımcı olacaktır. Bu da doğru bir hatırlama ile gerçekleşir. Hilekârı tespit etme gibi hayatta kalmayı arttıracak bilgilerin sonraki nesillere de aktarılabilir olmasını sağlayan bir bellek sistemimizin olduğu düşünülmektedir. Bu bellek sistemi adaptif bellek (adaptive memory) olarak adlandirilır ve bu bellek uyumsal problemlerimize çözüm üretmek için gerekli olduğu düşünülmektedir (Nairne ve ark. 2007).

Benzeri şekilde Cosmides ve Tooby (2015) de zihnimizin bilişsel modüllerden oluşmuş olduğunu ve bu bilişsel modüllerin her birinin uyumsal problemlere çözüm üretmek için oluşmuş olduğunu söylemektedir. Bazı araştırmacılar (Nairne ve Pandeirada 2008, Weinstein ve ark. 2008) kaynak belleğinin de yer aldığı epizodik belleğin, "hayatta kalma (survival)" bilişsel modülünü yansıttığını düşünmektedir. Yapılan bazı çalışmalar bu bakış açısını destekler niteliktedir. Örneğin, bir çalışmada yaşamsal önemi olan bilgilerle eşleşen yemekler (Deney1) ve arabalar (Deney2) için kaynak belleği avantajı olduğu gösterilmiştir (May ve ark. 2005). Ancak evrimsel psikolojinin önemli varsayımlarından olan bu bilişsel modüller ve diğer kavram problemleri araştırmacılar tarafından yeterli delillerin olmaması sebebiyle eleştirilmektedir (Panksepp ve Panksepp 2000, Barrett ve Kurzban 2006). Hilekâr1 tespit etme modülü (Cosmides ve Tooby, 2005) gibi hayatta kalma sürecinin altında yatan mekanizmalara temel bellek mekanizmalarıyla da açıklamalar getirmek mümkündür (Weinstein ve ark. 2008).

Uyaran ya da bilgi, ya aşağıdan yukarıya bir bilgi işlemeyle algisal olarak (algısal çarpıcılıkla örn. 1ş1ltısı, hareketi vb.) dikkati çeker ya da yukarıdan aşağıya bir bilgi işlemeyle algılayan kişinin beklentileri, şemaları, kalıp yargıları, amaçları vb. açısından uygunluğa göre öncelik açısından değerlendirilir (Mather ve Sutherland 2011). Mather ve Sutherland (2011) sunduğu duygusal uyarılma eğilimli rekabet modelinde (arousal-biased competition model) eğer eylem niyetli gerçekleşiyorsa ve bilgi öncelik taşıyorsa, kaynak belleğinin duygusal uyarılmışlıkla (arousal) geliştirilebileceğini iddia etmektedir. Bir başka deyişle, uyarılmaya sebep olan duygusal bir uyaran ya da bilgi yüksek öncelikli ise kaynak belleğini güçlendirir. Uyaran ya da bilgi hem duygusal uyarılmışlıkla hem de hayatta kalmayı destekleyici bir bilgi gibi öncelik kazanıyorsa kaynak belleğini güçlendirici bir etki yaratıyor olabilir. Bilginin, kişiyi zarardan koruma ya da fayda sağlama gibi öncelikli bir etkisinin olması durumunda kaynak belleği avantajı sağlanabileceği yorumu yapılabilir. Bir başka deyişle herhangi bir bilgi ve o bilginin bağlamı kişide öncelik uyandırıcı bir hatırlama motivasyonu geliştirdiğinde kaynak belleği performansının artması gözlenecektir. Bunun yanında Erdfelder ve Kroneisen'in (2013) derlemesinde bu ve bunun gibi hayatta kalma sürecinin altında yatan mekanizmaların daha genel bellek mekanizmalarını (domain-general memory mechanism) güçlendirici süreçlerle de açıklanabileceği görülmektedir.

Alan yazında, yukarıda bahsedilen karşılıklı etkileşimlerin (reciprocal interaction) deneysel olarak incelenebildiği görülmektedir. Karşlıklı etkileşimlerden fayda kazanan ancak bunun karşılığını göstermeyen kişileri hatırlayabilmek, sonraki etkileşimlerde onlardan kaçınmak ve hatta karşılıklı etkileşimin sonlanmasını sağlayabilmek açısından önemlidir. Mealey ve arkadaşları (1996) bu konuda ilk çalışmayı yapmıştır. Bu çalı̧̧mada araştırmacılar farklı davranış tanımlarıyla eşleştirdikleri insan yüzlerini katılımcılara sun- 
muşlardır. Çalı̧̧manın bulguları, katılımcıların sosyal etkileşimlerde bedavacı (freeloader), kazanç sağlayan ancak bunun karşıllğını göstermeyen olarak tanımlanan insanları, daha nazik davranışlarla tanımlanan insanlara göre daha iyi hatırladığını göstermiştir. Yüzü (içerik belleği) ve onu tanımlayan davranış detaylarını hatırlayabilmek (kaynak belleği) hem doğrudan hem de dolaylı olarak karşılıklı etkileşimlerde önemlidir. Bu sebeple insanlar, hilekâr kişileri hatırlamanın diğer kişilere göre daha önemli olduğunu ya da öncelik taşıdığını düşünüp onlara daha uzun süre bakıyor olabilirler (Chiappe ve ark. 2004). Ancak bu konuda ne kadar başarılı oldukları derlemenin diğer başlıklarında daha detaylı bir şekilde incelenecektir.

\section{Sosyal kaynak belleği: davranış detayları verilen yüzler}

Reisberg'e (2010) göre yüz, farklı bir tanıma sistemine sahiptir. Her yüzün birbirinden farklı özelliklere sahip olduğunu kabul edersek, yüz tanıma adeta bir barkod okuma sistemi gibidir. Diğer bireylerin yüzünü tanımak, sosyal yaşamın bir gereğidir. Özellikle hangi bireyin dost, hangi bireyin düşman olduğunu tanıyabilmek ya da ayırt edebilmek sosyal yaşamın vazgeçilmez bir gerekliliğidir. Bu sebeple sosyal kaynak belleğini araştıran araştırmacıların çoğu, sosyal bilgiyi atfetmek için çalışmalarında yüzler kullanmıştır (örn. Bell ve Buchner 2010, 2011, Bell ve ark. 2012a, 2012b, 2012c, Righi ve ark. 2015, Bell ve ark. 2015). Bu çalışmaların yöntemlerinde genel olarak yüzlerle eşleşen cümleler bulunmaktadır. Bu cümlelerin ekranda görünen kişinin davranışlarını ifade ettiği bilgisi verilmektedir. Örneğin, Bell ve arkadaşlarının (2012a) çalışmasında bir yüz "K. S. ikinci el araba satıcısıdır. Kaza yapan arabaları tamir edip satmakta ve müşterilerinden bu araçların ciddi kusurlarını gizlemektedir.” cümlesi ile eşleştirilmiştir. Çalışmalarda bu gibi davranış detayları manipüle edilerek kaynak belleği üzerindeki etkisi araştırılmaktadır. Örneğin; yüzler; iğrenme, hoşa giden (pleasant; Bell ve Buchner 2010), güvenilir, hilekâr (Bell ve Buchner, 2011, 2012a, 2012b), suçu işleyen, mağdur (Bell ve Buchner 2011Deney 2) ve nötr davranış tanımlarıyla veya yüz ile duygusal olarak uyumlu ve uyumlu olmayan sahnelerle (Righi ve ark. 2015) beraber sunulmuştur. Çalışmaların çoğunda test aşamasında yarısı yeni, yarısı çalışma aşamasında görülmüş yüzlerden oluşan uyaranlar rastgele bir şekilde katılımcıya sunulur. Sonrasında katılımcılardan sunulan yüzün eski mi ya da yeni mi olduklarını ayırt etmeleri istenir. Eski olarak seçilen yüzler için kaynak belleği görevinde katılımcılardan, çalışma aşamasında o yüz ile eşleşen davranış tanımlarına ilişkin kategorilerin bulunduğu şıklardan bir tanesinin seçilmesi istenir (Bell ve Buchner 2010, 2011, Bell ve ark. 2012a, 2012b, 2012c, 2015). Genel olarak, davranış detayları verilen yüzler için sosyal kaynak belleğinin, duygu değerliği (valence) ve duygusal uyarılmışlık düzeyinden, kalıp yargılarla beklentilerin farklı olması durumundan, şema ve beklentilerin uyumluluk-uyumsuzluk durumundan, iç grup-dış grup yanlılıklarından, bilginin öz ile ilişkili olması durumundan, detaylı ya da yüzeysel kodlama süreçlerinden etkilendiği görülmektedir. Bu faktörler aşağıdaki her bir paragrafta, sırasıyla ve daha detaylı olarak incelenmiştir.

Pozitif ve nötr davranış tanımlarıyla eşleşen yüzlere göre negatif içerikli davranış tanımlarının eşleştiği yüzler için kaynak belleğinin daha iyi olduğu gösterilmiştir (Bell ve Buchner 2010, 2011- Deney 2, Bell ve ark. 2012a, 2012b). Bir yüz negatif içerikli bir davranış tanımıyla eşleştiğinde, sonrasında o yüzü tanımlayan davranışı hatırlamak kolaylaşmaktadır. Bir başka deyişle kodlama aşamasında iğrenme uyandıran, suç işleyen birini tanımlayan veya hilekârlık yapan birini tasvir eden davranış tanımlarıyla (negatif davranı̧̧ 
tanımıyla) eşleşen yüzler, test aşamasında tekrar görüldüğünde kodlama aşamasında hangi davranış tanımıyla (kategorik olarak) eşleştiği daha iyi hatırlanmaktadır (sırasıyla Bell ve Buchner 2010, 2011- Deney 2, Bell ve ark. 2012a, 2012b). Ancak negatif davranış tanımları için bu avantaj sadece pozitif ve nötr davranış tanımlarıyla kıyaslandığında ortaya çıkıyor gibi görünmektedir. İğrenme uyandıracak ve hilekârlık yapan birini tasvir eden davranış tanımları gibi farklı içeriklere sahip negatif davranış tanımlarıyla eşleşen yüzlere ilişkin kaynağın doğru hatırlanmasında bir farkın olmadığı bulunmuştur (Bell ve ark. 2012c- Deney 1). Ancak yüzler saldırganlığın kendine ya da bir başkasına olduğunu belirten davranış tanımlarıyla eşleştiğinde, saldırganlığı başkasına gösteren yüzlere dair kaynak bilgisinin daha doğru hatırlandığı gösterilmiştir (Bell ve ark. 2012c- Deney2). Bu bulgular negatif bağlamda olan yüzlerin bağlamıyla daha iyi kodlandığını ve hatırlama aşamasında daha doğru hatırlanabildiğini göstermektedir. Bunun yanında yüzlerle eşleşen bilgilerin hem negatif hem de tehdit içerikli bir durumu ifade ediyor olmasının kaynak belleği avantajı sağladığı görülmektedir. Ancak kaynak belleği avantajı sadece negatif bağlamla sınırlı değildir. Benzer şekilde pozitif (pleasant) bağlamlarla eşleşen yüzler için nötr bağlamla eşleşenlere göre kaynak belleği avantajı görülmektedir (Bell ve Buchner 2010). Her ne kadar Mattarozzi ve arkadaşlarının (2018) çalışmasında kaynak belleği ölçülmüş olmasa da, olumlu ve olumsuz davranış tanımlarıyla eşleşen yüzlerin sadece kısa süreli hatırlamada değil uzun süreli hatırlamada da etkili olduğu gösterilmiştir. Yazarlar bu bulgularını olumlu ve olumsuz eylemlerle eşleşen kişileri hatırlamanın işlevsel olduğunu ve bu durumun sonraki olası ilişkilerimizi düzenlediği üzerinde durmuştur. Ancak bu kişileri uzun süreli hatırlamada sadece doğru hatırlamak ilişkilerimizi düzenlemede işlevsel olmayabilir. Aynı zamanda onlarla eşleşen eylemleri de doğru hatırlamamız ilişkilerimizi düzenlemek için gerekli gibi görünmektedir.

Bir önceki paragrafta bahsedilen çalışmaların da gösterdiği gibi duygu değerliği, kaynak belleği üzerinde etkilidir. Ancak duygu değerliğinin yanında duygusal uyarılmışlı̆̆ın da bilginin kodlanmasında ve geri getirilmesinde önemli olduğu bilinmektedir (Kensinger 2004, 2009). Bu sebeple davranış tanımlarının da bu bağlamda değişimlenerek incelenmesi önemlidir. Bell ve Buchner (2011)'ın yaptığı çalışmada negatif davranış tanımı, pozitif davranış tanımına göre duygu değerliği ve duygusal uyarılmışlık açısından düşük kaldığında negatif eylemlerle eşleşen yüzler için kaynak belleği avantajının ortadan kalktığ1 görülmektedir. Bir başka deyişle hilekâr davranış tanımı, güvenilir davranış tanımından duygu değerliği ve duygusal uyarılmışlık açısından düşük kaldığında bu tanımlarla eşleşen yüzler için kaynak belleği performanslarının farklılaşmadığı görülmektedir (Bell ve Buchner 2011-Deney 1). Ancak hilekâr ve güvenilir davranış tanımlarıyla eşleşen yüzler beraber ele alınıp nötr davranış tanımlarıyla eşleşen yüzlerle kıyaslandığında daha iyi kaynak belleği performansına sahip olduğu gösterilmiştir (Bell ve Buchner 2011Deney 1).

Buraya kadar olan çalı̧̧maları değerlendirmek gerekirse, davranış tanımıyla yüzün bağlanmasında duygu değerliğinin ve duygusal uyarılmışlı̆̆ın etkisinin önemli olduğu görülmektedir. Bir başka deyişle bir davranı̧̧ tanımının duygu değerliği ve duygusal uyarılmışlık açısından yüksek olması, o davranışın hangi yüzle eşleştiğinin daha iyi hatırlanmasına sebep olabilir. Sosyal etkileşimlerde, bahsedilen deneylerde olduğu gibi bir kişiyle ilgili bir başkasından olumlu ya da olumsuz bilgiler öğrenerek, sonraki olası eylemlerimiz için gerektiğinde bu bilgiyi hatırlayarak kullanıyor olabiliriz. Ancak bir kişiyle dolaylı ya da doğrudan olan deneyimlerimiz dişında, o kişinin görünümünden elde edilen yargılar ya da değerlendirmeler de kişi/kişilere ilişkin eylemlerimize yön veriyor olabilir. Çoğu 
zaman kişiler hakkında adına "ilk izlenim" dediğimiz bu yargıları oluşturuyor ve bu yarg1lar sonucunda ürettiğimiz teorilerden etkilenerek eylemlerimizi sürdürebiliyoruz (Cook ve ark. 2003).

Çalışmalar insanların, kişilerin davranışlarını hatırlamaya çalışırken, bir başka deyişle kaynağı hatırlarken, kişilerin diş görünüşlerinden elde ettikleri kalıp yargılardan etkileniyor olduklarını göstermiştir (Cassidy ve ark. 2012, Kleider ve ark. 2012, Kuhlmann ve ark. 2016). İnsanların özellikle kişileri sınıflandırırken o kişilerin yüzlerinden elde ettikleri ipuçları otomatik ve tepkisel olarak kullandıkları gösterilmiştir (Kleider ve ark. 2012). Ancak bu sınıflandırmanın çoğu zaman yanlı̧ olabileceği ve bir yanlılığa işaret ettiği söylenebilir. Örneğin kaynak belleği testinde bir kişinin suça bulaşıp bulaşmadığını değerlendirirken, sağlam bir hatırlama yaşamadan o kişinin yüzünden elde edilen ipuçlarından etkilenildiği gösterilmiştir (Kleider ve ark. 2012). Katılımcılar bir ifadeyi kimin söylediğine dair iyi bir hatırlama yaşamasa da, o ifadenin hangi yaş grubuna ait olabileceğine dair kalıp yargılarını kullanarak kaynak izleme yapmaktadır (Kuhlmann ve ark. 2016). Kuhlmann ve arkadaşları (2016) iyi bir kaynak belleğine sahip olmanın, hem yaşlı hem de genç katılımcılarda daha az kalıp yargılarla ilişkili kaynak izleme yanlılığına sebep olabileceğini göstermiştir. Bir kişi hakkındaki detayları hatırlamamız istendiğinde, aslında sağlam olmayan bir hatırlama ile o kişinin yüz görünümünden oluşturduğumuz kalıp yargılardan etkileniyor gibi görünmekteyiz. Bir kişi hakkında elde ettiğimiz kalıp yargılarımız bazen desteklenirken, bazen desteklenmez. Bu durumda, o kişi hakkında oluşturduğumuz beklentiyle bir uyumsuzluk ya da uyumluluk oluşabilmektedir. Örneğin gülen bir yüz ifadesine sahip bir kişiyle ilgili olumlu bir beklenti oluştururuz. Ancak bazen bu olumlu beklentimiz o kişinin olumsuz davranışlarıyla (örn. hilekar davranmasıyla) bozulmaktadır. Bu durumda beklenti ile uyuşmayan bir durum oluşur.

Suzuki ve Suga (2010) yüzden elde edilen ipuçlarıyla oluşan beklentinin, sonrasında karşılanmaması durumunda ortaya çıkan uyumsuzluğun (incongruity) kaynak belleği performansı üzerinde olumlu yönde etkisi olduğunu göstermiştir. Uyumsuzluğun yanında şema ile tutarsızlı̆̆ın (inconsistency) da kaynak belleği performansı üzerinde sadece yüksek beklenti koşulunda etkili olduğu gösterilmiştir (Küppers ve Bayen 2014). Kat1lımcılar bellek izleri zayıf olduklarında, şema ile uyumlu tahmin yanlılıkları gösterirler (Küppers ve Bayen 2014). Nitekim bazı çalışmalarda yüz görünümüyle, o yüzün sergilediği davranışı tasvir eden açıklamanın uyumlu olmamasının kaynak belleği performansını arttırıyor olduğu gösterilmiştir (Bell ve ark. 2015). Bir başka deyişle yüzün görünümünün uyandırdığı beklentiyle tutarlı olmayan davranış tanımlarına ilişkin kaynak belleği avantajı görülmektedir. Örneğin hoşa gitmeyen bir yüz ifadesinin, hoşa giden bir davranış tanımıyla eşleşmesi, zeki görünmeyen yüz ifadesinin zeki olma davranışsal açıklamasıyla eşleşmesi ve çiftçi görünümünde birinin avukat davranış tanımıyla eşleşmesi halinde kaynak belleği avantajı görülmektedir (Bell ve ark. 2015). Ancak yine de Küppers ve Bayen (2014) şema ile uyumsuz bilginin kaynak belleği avantajı oluşturabilmesi için beklenti düzeyinin etkili olduğunu belirtmektedir. Benzeri bir şekilde başka bir çalışmada katılımcıların olumsuz ve nötr beklenti oluşturmaları sağlanır ve bu beklentilerin kaynak belleği performansı üzerindeki etkisi incelenmiştir (Kroneisen ve ark. 2015). Bu çalışmada agresif (olumsuz) bireyler göreceğini sanan grup, bu kişiler olumlu davranışlar sergilediğinde, olumsuz davranışlar sergilemesine göre daha iyi bir kaynak belleği performansı göstermiştir. Bu çalışmalardan, yüksek beklenti ve olumsuz beklenti ihlali durumunda daha iyi bir kaynak belleği performansı geliştirdiğimiz çıkarımı yapılabilir. Başka bir çalışmada genç yetişkin katılımcılara, bebek yüzlü ya da daha olgun görünümlü yüzler, ya 
uysal ya da baskın kişilik özelliklerini yansıtır davranış tanımlarıyla eşleştirilerek sunulmuştur (Cassidy ve ark. 2012). Genç katılımcıların sadece yaşlı yüzlerin uyumsuz eşleşmelerinde kaynak belleği performansları daha iyidir. Bu durum genç yetişkinlerin, yaşlı kişiler gibi gruplarının dışında olan kişilerin uyumsuzluklarına karşı daha iyi bir kaynak belleği performansı geliştirmiş olabileceklerine işaret etmektedir. Bu çalı̧̧ma katılımcıların kaynak belleği performanslarının, karşılaşılan yüzlerin kendi grubundan olup olmama durumdan da etkilenebileceğini düşündürmektedir.

Yapılan çalışmalarda hatırlanması istenen kişilerin ait oldukları grupların da kaynak belleği üzerinde etkili olduğu gösterilmiştir (Greenstein ve ark. 2016, Hechler ve ark. 2016). Her ne kadar Cassidy ve arkadaşlarının (2012) çalışmasıyla benzer sonuçlar elde edilmese de, iç grup olduğu düşünülen kişiler için kaynak belleği avantajı olduğu gösterilmiştir (Greenstein ve ark. 2016). Benzeri şekilde bu kaynak belleği avantajı grup düzeyinde beklenti ihlali olduğunda da daha güçlü gibi görünmektedir (Hechler ve ark. 2016). Örneğin Hechler ve arkadaşlarının (2016) çalışmasında iç grup üyelerine karşı olumlu bir bellek yanlılığı olsa da, işbirliği yapmayan iç grup üyeleri için, işbirlikçi iç grup üyelerine göre daha iyi kaynak belleği performansı olduğu gösterilmiştir. Ancak aynı çalışmada bu kaynak belleği avantajının işbirlikçi olan ya da olmayan dış grup üyeleri için olmadığ1 gösterilmiştir. Bu çalışmada olumlu beklenti ihlalinin etkisinin kaynak belleği üzerinde etkili olduğu ancak bu etkinin iç grup üyeleri için sınırlı kaldığı gösterilmiştir. İç grup üyeleriyle gelecekte ilişki kurma ihtimalimizin daha yüksek olması sebebiyle beklentiyle ilişkili uyumsuzluğa daha iyi bir kaynak belleği performansı gösteriyor olabiliriz. Bazı çalışmalar öze başvurmanın (self-reference) kaynak belleği üzerinde olumlu etkisi olduğunu göstermiştir (Leshikar ve Duarte 2012, Genon ve ark. 2014, Durbin ve ark. 2017). Bu durum iç grup üyeleri gibi gelecekte öz ile ilişkili (self-related) olacak kişiye ya da bilgiye karşı kaynak belleği avantajını ortaya çıkarıyor olması ihtimalini düşündürmektedir.

Kroneisen (2017) de benzeri şekilde öz ile ilişkili süreçlerin kaynak belleği üzerinde etkili olabileceğini düşünmüştür. Yaptığı çalışmada deney öncesinde davranış tanımları, katılımcılarla ilişkili olan ve olmayan bir şekilde düzenlenmiştir. Deney aşamasında bu davranış tanımları yüzlerle eşleştirilerek katılımcılara sunulmuştur (Kroneisen 2017). Çalışmada öğrencilerin kendileriyle daha ilişkili olduklarını söyledikleri hilekârlık durumlarıyla eşleşen yüzlere ilişkin kaynak belleği doğruluğunun daha yüksek olduğu gösterilmiştir. Ancak öğrencilerin kendileriyle ilişkili olduklarını söyledikleri güvenilir ve hilekâr davranış tanımlarıyla eşleşen yüzlere karşı kaynak belleği doğruluğunda bir fark göstermemesi, öz-ilişkili süreçlerin kaynak belleği performansında önemli bir rol oynadığını göstermektedir. Kroneisen (2017) bir yüze ilişkin kaynak belleği avantajının oluşabilmesi için bağlamın kişi için önemli ve ilişkili olmasının gerektiğini göstermiştir.

Yukarıda bahsedilen çalışmalarda, kaynak belleği kategorik olarak ölçülmüştür. Bu çalışmalar kaynağı izlerken tam anlamıyla ne hatırlıyor olduğumuzun cevabını vermemektedir. Ancak bir çalışmada (Bell ve ark. 2012a), katılımcılardan çalışmada yüzle eşleşen davranış tanımına ilişkin detayları mümkün olduğunca hatırlamalarını ve o detayları yazmaları istenir. Çalışmada katılımcıların yüzlerle eşleşen davranış tanımlarının detaylarını hatırlamada oldukça kötü oldukları gösterilmiştir. Yani yüz ile eşleşen hilekârlık, güvenilirlik ve nötr davranış tanımlarının detaylarına dair neredeyse çok az şey hatırlanmaktadır. Dolayısıyla araştırmacılar kaynak belleğinin kısmi/kategorik (partial) ve özgü (specific) olarak ayırarak aslında katılımcıların hilekâr yüzlere karşı kısmi kaynak belleği avantajı taşırken, özgü kaynak belleği avantajı için üç koşulun birbirinden farklılaşmadı- 
ğını göstermiştir (Bell ve ark., 2012a). Katılımcılar yüzle eşleşen davranışın içeriğine dair neredeyse hiçbir şey hatırlamaması, davranış içeriklerinin detaylarından daha çok onların özünün (gist) daha iyi kodlanıyor ve hatırlama esnasında kategorik bir hatırlama yapılıyor olduğunu göstermektedir. Bell ve arkadaşları (2012b- Deney4) duygusal olarak yüz ve davranış tanımı arasında uyumsuzluk yaşamanın, davranış tanımının detaylarını daha ayrıntılı kodlayıp hatırlayabilmemize yarar sağlayabileceğini düşünmüştür. Bu çalışmada katılımcılara ipucu verilerek daha detaylı hatırlamaları için desteklenmiştir. İpucu verilen katılımcılarda, yüz ve davranış tanımında yaşanan duygusal uyumsuzluğun, genel kaynak belleği performansını arttırmasının yanı sıra davranışın daha detaylı hatırlanmasına da sebep olmuştur (Bell ve ark. 2012b- Deney4). Bir başka deyişle duygusal uyumsuzluk, özgü kaynak belleği performansının da artmasını sağlamış gibi görünmektedir. Bunun yanında sosyal kaynak belleği ölçümünün değerlendirilmesinde bilinçli bir hatırlamaya mı eşlik ettiği (remember judgement) yoksa bilinçli bir hatırlama olmadan bir aşinalık hissine mi dayanarak gerçekleştiği (know judgement) sorusuna cevap eksik kalmıştır. Bu soruya hatırlama/bilme paradigması ve kaynak belleği görevi birleştirilerek cevap verilebilir. Sosyal bilgide algısal ya da bağlama ilişkin detayların hatırlanmasında etkili olan faktörlerin, bilinçli bir hatırlama ya da aşinalık hissine dayalı bir hatırlama sürecinde nasıl etkiler göstereceği konusu eksiktir ve bu konuda çalışmaların yapılması gerekmektedir.

\section{Sosyal işbirliği oyununda sosyal kaynak belleği}

İ̧̧birliği ve çatışmalar sosyal hayatın bir parçasıdır. Bu tür etkileşimlerde kişilere dair nasıl bir hatırlama sürecine dahil olduğumuz son zamanlarda araştırmacıların ilgisini çekmektedir. Kaynak belleğinin, hem işbirliği kurabileceğimiz kişileri bulmak için hem de hilekâr kişilerden uzak kalmak için önemli olduğu gösterilmiştir (Bell ve ark. 2017b). Hilekârı tespit etme modülünde hilekârları tespit etmek için özelleşmiş bir sistemden bahsedilir (Cosmides ve Tooby 2005). Ancak hilekâr ve işbirlikçi kişileri ayırt edebilmek için sadece hilekârları değil işbirlikçi olan kişilere dair bilgiyi de doğru bir şekilde hatırl1yor olmamız gerekmektedir.

Gerçekçi bir sosyal etkileşim yaratabilmek için araştırmacılar sosyal işbirliği oyunu ya da bir diğer adıyla tutsak ikilemi oyunu kullanarak kaynak belleği performansını ölçmüştür. Bu oyunda katılımcılar sosyal etkileşimden kar ya da zarar elde etmektedir. Örneğin, Bell ve arkadaşlarının (2012b- Deney1 ve Deney2) çalışmasında katılımcılara oyun başında bir bakiye verilmektedir. Bu bakiye üzerinden karşılaşacakları ortaklarla ortak bir şirket için yatırım yapmaları ve bakiyelerini arttırmaları istenir. Ĕğer karşılaşacakları ortak işbirlikçiyse en az katılımcı kadar yatırım yaparken; ortak hilekârsa katılımcının yaptığ1 yatırım miktardan daha az ya da hiç yatırım yapmaz. Toplam yatırıma üçte bir oranında ödül verilmektedir. Sonunda elde edilen yatırım miktarı ikiye bölünerek iki tarafın bakiyesine eklenir. Örneğin, bir katılımcıya oyun başında 500 puanlık bir başlangıç sermayesi verildiğini düşünelim. Katılımcılar yatırım yaparken 75 ya da 150 puanlık yatırım yapabilmektedir. Katılımcı 150 puanlık bir yatırım yapar ve karşılaşacağı ortak da işbirlikçi çıkarsa en az katılımcı kadar yatırım yapacaktır. Bu durumda toplam sermaye 300 puan olacak ve sistem üçte bir oranında hediyeyi (100 puan) sermayeye ekleyip (400 puan) ikiye bölecektir (200 puan). Yani son durumda katılımcı ve ortağ1 150 puanlık bir yatırıma karşılık 200 puanlık karşılıklı kazanç elde etmiş oldu. Ancak katılımcı, hilekâr bir ortak ile karşılaşmış olsaydı ortağı hiç ya da az yatırım yapacaktı. Örneğin katılımc1nın150 puanlık yatırımına karşılık, hiç yatırım yapmayacak bir ortak ile karşılaştığını 
düşünelim. Toplam sermaye (150 puan) üçte bir ödülüyle beraber (50 puan) 200 puan edecek ve bu toplam puanın yarısı yatırımcıların hesabına geçecektir. Bir başka deyişle hilekâr ortak hiç yatırım yapmadan 100 puan kazanmış olacaktır. Katılımcı da 150 puanlık yatırımına karşılık 100 puan alarak zarar edecektir. Oyun bittikten sonra test aşaması yönergelerle başlar. Bu aşamada katılımcıların oyunda karşılaştıkları yüzlere ek olarak yeni yüzler eklenir ve katılımcılara sunulur. Katılımcılardan bu yüzlerin eski mi yeni mi olduğunu ayırt etmeleri istenir. Eski cevabını takiben katılımcılardan ortaklarının oyunda yaptığ1 yatırım stratejilerini düşünerek hilekâr mı yoksa güvenilir mi olduğu sorulur.

Bir önceki başlıkta çalışmaların büyük birçoğunda beklenti ihlalinin kaynak belleği üzerinde etkili olduğundan bahsedilmiştir. Benzeri bir etkinin sosyal işbirliği oyununda da olup olmadığı araştırılmıştır. Sosyal işbirliği oyununda da beklentimizle uyuşmayan bilgi için kaynak belleği avantajı gösterildiği bulunmuştur (Bell ve ark. 2012b). Bu çalışmada katılımcıların karşılaşacakları ortaklarının yüzleri yüksek beğenilir ya da düşük beğenilir puanlar alan (Bell ve ark. 2012b- Deney1) ve gülümseyen ya da kızgın (Bell ve ark. 2012b- Deney2) yüz fotoğraflarından oluşmaktadır. Bu ortaklar ya hilekâr ya da işbirlikçi koşullarda yarısının cinsiyeti kadın, yarısının cinsiyeti erkek olacak şekilde sunulur. Oyun öncesinde yüzleri daha beğenilir (Bell ve ark. 2012b- Deney1) ve gülümseyen (Bell ve ark. 2012b- Deney2) olanların işbirlikçi olacağı beklentisi taşıyan katılımcılar, beklentileriyle ters davranışlar ile karşılaştıklarında bu davranışları daha iyi hatırlamaktadır (Bell ve ark. 2012b-Deney1 ve Deney2). Katılımcıların gülümseyen ve beğenilir görünen yüzlere karşı daha çok yatırım yapmaları, o kişilere karşı olumlu bir beklenti içerisinde olduklarının bir göstergesi olabilir (Bell ve ark. 2012b, Giang ve ark. 2012). Benzeri şekilde bu durum katılımcıların kızgın yüz ifadesine sahip ortaklardan daha çok, gülümseyen ortaklara karşı daha fazla işbirliği yanlılığı göstermesiyle de desteklenmektedir (Bell ve ark. 2017b). Gülen ya da beğenilir görünen bir kişinin işbirlikçi bir durumu daha çok desteklediği yorumu yapılabilir. Bir başka deyişle yüzden elde edilen ipucuyla olumlu bir beklentinin oluşması, işbirlikçi bir durumu desteklemektedir.

Beklentiler karşılanmadığında, o kişilere ilişkin detaylar zihnimizde daha kalıcı olduğu görünmektedir. Yani kişilere karşı oluşturduğumuz izlenimle uyuşmayan davranışlar ile karşılaştığımızda, onların bu beklenti dışı davranışlarına dair kaynak belleği daha iyidir. Daha detaylı inceleyecek olursak Bell ve arkadaşlarının (2012b) çalışması gülümseme ve beğenilir görünme gibi olumlu beklenti yaratan yüzlerin, beklenti dı̧̧ı davranması sonucunda kaynak belleği performansının olumlu etkilendiğini göstermiştir. Olumlu olan beklentilerin ihlali durumunda, olumsuz olan beklenti ihlaline göre kaynak belleği performansının daha iyi olduğu gösterilmiştir. Bir başka deyişle olumsuz beklenti taşıdığımız kişilerin olumlu davranış özelliklerini deneyimlesek bile bu davranışı sergileyen kişiye karşı iyi bir kaynak belleği performansı göstermemekteyiz. Benzer bir şekilde başka bir çalışmada her ne kadar hilekâr görünen işbirlikçiler için kaynak belleği avantajı görülmemiş olsa da, güvenilir görünen hilekârlar için kaynak belleği performansının daha iyi olduğu gösterilmiştir (Mieth ve ark. 2016). Sosyal işbirliği oyunlarında, olumlu beklentinin ihlal edildiği durumlarda kaynak belleği avantajı olduğu görülmektedir. Bu kaynak belleği avantajı, görevlere bilişsel yük eklense de ortaya çıkmaktadır (Mieth ve ark. 2016a- Deney2 ve Deney3).

Olumlu beklentinin ihlali durumu katılımcılar için öncelikli bir durum taşıor gibi görünmektedir. Örneğin Mieth ve arkadaşları (2016b) sosyal işbirliği oyununda, güvenilir yüz görünümünün cezalandırma üzerindeki etkisini incelemiştir. Mieth ve arkadaşları (2016b) katılımcıların olumlu beklentilerini ihlal eden ortaklarla karşılaştıklarında onları 
cezalandırmak için daha fazla para harcadıklarını göstermiştir. Katılımcılar beğenilir ya da gülümseyen yüze sahip ortaklarla daha çok işbirliği yapmak istemektedir ancak ortaklar hilekâr bir davranış sergilerse bu durum ahlaki bir cezalandırma için fırsat doğurmaktadır (Mieth ve ark. 2016b). Benzeri etki kadın cinsiyeti için de gösterilmiştir. Katılımc1lar işbirliği oyununda kadın ortaklarının daha fazla işbirlikçi olduğunu söyleme yanlılığı gösterir (Mieth ve ark. 2017). Ancak kadın ortaklar hilekâr çıkarsa, katılımcıların onları cezalandırmak için daha fazla para harcadıkları gösterilmiştir (Mieth ve ark. 2017). Bu çalışmalar olumlu beklenti ihlalinin öncelikli bir bilgi olabileceğini desteklemektedir. Katılımcılar oyunda olumlu beklenti yaratacak bir ortak ile karşılaştıklarında muhtemelen daha çok yatırım yaptıklarından daha çok parasal kayıp yaşamaktadır. Parasal kaybın büyüklüğü muhtemelen kişileri daha iyi hatırlamamıza sebep olmaktadır.

Son zamanlarda yapılan bir çalışmada sosyal işbirliği oyununda işbirlikçi ve hilekâr yüzler için kaynak belleği performansının değişmediği gösterilmiştir (Schaper ve ark. 2019). Bu durum bir önceki başlikta çeşitli davranış tanımlarıyla eşleşen yüzlerin bulunduğu deneylerin bulgularıyla ters düşüyor gibi görünmektedir. Ancak sosyal işbirliği oyunlarında parasal bir motivasyonun bulunması sonraki hatırlamalar için teşvik edici bir durum oluşturduğundan kaynak belleği performansını etkiliyor olabilir. Bir başka deyişle kâr ya da zarar durumunda, kâr miktarımızı maksimuma çıkarmamız için "kısasa kısas" da olduğu gibi hilekâr ve işbirlikçi kişileri eşit derecede iyi hatırlamamız gerekmektedir. Hilekârı tespit etme modülünde (Cosmides ve Tooby 2005) varsayıldığı gibi sadece hilekârlar için özelleşmiş bir sistemimizin olmadığı görülmektedir. Nitekim Schaper ve arkadaşları (2019) çalışmasında katılımcıların işbirliği yapma isteklerinin bir önceki oyunda gördükleri ortaklarının davranışından etkilendiğini göstermiştir. Bunun yanında kaynak belleği performansı ile işbirlikçi ve hilekâr kişileri ayırt etme arasında bir ilişki olduğu gösterilmiştir. Bir başka deyişle kaynak belleği iyi olan katılımcılar işbirlikçi ortaklarla daha fazla ve hilekâr ortaklarla daha az işbirliği yapmışlardır.

Sosyal işbirliği oyununun teşvik edici doğası ele alınarak çalışmalar değerlendirilmelidir. Bunun yanında insanın sosyal etkileşimdeki işbirlikçi doğasında farklı etkilerin de bulunabileceği göz ardı edilmemesi gerekmektedir. Örneğin bir grup içerisinde işbirliğinde bulunmak (Zappa 2012) ve işbirliği içerisinde olduğumuz kişinin kendimize benzerliği (Giang ve ark. 2012) gibi etkenler davranışlarımızı ve dolayısıyla nasıl bir hatırlama sürecine girdiğimizi etkiliyor olabilir. Kendimize benzer bireylere daha çok yardım ediyor ya da onlara karşı daha olumlu bir beklenti içerisine giriyor olduğumuz düşünülebilir. Ancak yapılan bir çalışmada katılımcılara fiziksel olarak benzeyen yüzlere karşı iyi bir kaynak belleği performansı gösterilmediği bulunmuştur (Giang ve ark. 2012). Bunun yanında katılımcılara benzeyen yüzler için işbirlikçi olduklarını düşünme yanlılı̆̆ $1 \mathrm{da}$ gösterilmemektedir (Giang ve ark. 2012). Giang ve arkadaşlarının (2012) çalışmasında katılımcılara benzeyen yüzlerin uyaran olarak hazırlanması oldukça yapaydır. Örneğin oyunda karşılaştığ 1 ortağının gözleri, katılımcının önceden çekilmiş fotoğrafında bulunan gözleriyle değiştirilerek uyaran yüz olarak sunulmuştur. Bir kişinin diğgeriyle olan benzerlik düzeyi, yüzün fiziksel olarak belli parçaları ile benzer olmasıyla başarılı bir şekilde manipüle edilmiyor olabilir. Örneğin bir olay ya da duruma karşı diğger kişi ile benzer bir tutum sergilemek yüzün fiziksel olarak benzerliğinden daha çok etki ediyor olabilir.

Grup etkileşimlerinde ise hilekârlara göre işbirlikçilerin daha iyi hatırlandığ gösterilmiştir (Zappa 2012). Bu gibi faktörlerin sosyal kaynak belleğinin temel bilişsel mekanizmalarını açıklamada önemli olduğu görülmektedir. Bunların yanında bireysel farklılıklar da sözü edilmesi gereken bir diğer konudur. Sosyal ikilemlerdeki bireysel farklilık- 
ları araştıran çalışmalarda sıklıkla kullanılan ve bireylerin sosyal ikilemler karşısında sahip olduğu düşünülen sosyal değerlerin, insanların davranışlarını belirlediği düşünülmektedir (Van Lange ve Kuhlman 1994, Van Lange ve ark. 1997, Balliet ve ark. 2009). Bireylerin sosyal değer yönelimlerinin sosyal işbirliği oyunundaki hem işbirlikçi davranışlarına hem de etkileşim kurdukları ortaklara ilişkin bellek süreçlerinde etkisi olduğu düşünülebilir.

\section{Tartışma}

Derlemede özetlenen görgül çalışmalar, sosyal bilgiye ilişkin kaynağın geri getirilmesi sürecinde negatif bilgiye daha çok eğilim gösterildiğine işaret etmektedir (Bell ve Buchner 2011, Bell ve ark. 2012b). Ancak bir bilginin kaynağını geri getirmede iyi bir performans gösterebilmenin, o bilginin sadece negatif olup olmama durumuna bağlı olarak geliştiğini söylemek basit bir açıklama olacaktır. Bell ve Bucher (2012a) bu durumla ilgili olarak özellikle bilginin tehdit içermesi (Bell ve ark. 2012c) ve gözleyenler ya da katılımcılar açısından olumsuz sonuçlar doğurması ihtimali olan durumlarda kaynak belleği avantajının gözlendiğini söylemektedir. Ancak bilgi negatif ya da tehdit içerikli olmasa da kaynak belleği avantajı oluşabildiği diğer çalışmalarda gösterilmiştir (Bell ve Buchner 2010, Bell ve ark 2015, Kroneisen 2017). Bu sebeple sadece negatif ya da tehdit içerikli bir bilgide kaynak belleği avantajı ortaya çıkmıyor gibi görünmektedir. Duygu değerliğinin ve duygusal uyarılmışlığın da davranış tanımlarıyla eşleşen yüzleri değerlendirirken kaynak belleği üzerinde etkili ve önemli olduğu görülmektedir (Bell ve Buchner, 2011).

Bir kişiye ait belli detayları hatırlamaktansa o kişiye atfettiğimiz kategoriyi hatırlamak daha az bilişsel kaynağın kullanılmasını gerektirir (Bell ve ark. 2012a). Bu durum aslında büyük ölçüde davranı̧̧ detayları bilinmeyen, kategorik bir hatırlama sürecini benimseyen ya da bellek yükünü azaltmak üzere kullanılan bir stratejiye işaret ediyor gibi görünmektedir. Kaynak belleğinin detaylı bir kaynak bilgisine sahip olunmaksızın, canlı bir hatırlamaya katılmadığı ve belirsiz bir bellek biçimini yansıtıyor olabileceği gösterilmiştir (Bell ve ark. 2012a).

Tanyaş ve Mısırlısoy (2018)'un da bahsettiği gibi bellek izi zayıf olduğunda kalıp yargıların ve şemaların kaynak belleği üzerinde güçlü etkileri olmaktadır. Çalışmalarda kaynağ1 izlerken büyük ölçüde kalıp yargılarımızdan (Cassidy ve ark. 2012, Kleider ve ark. 2012, Kuhlmann ve ark. 2016) ve beklentinin ihlal edildiği durumlardan (Bell ve ark. 201, Küppers ve Bayen 2014, Suzuki ve Sugo 2010) etkileniyor olduğumuz gösterilmiştir. Beklenti ihlali durumunda kaynak belleği avantajının görülebilmesi için hem beklenti düzeyinin yüksek (Küppers ve Bayen 2014) hem de olumsuz beklenti ihlali (Bell ve ark,2015, Kroneisen ve ark. 2015) olması gerekiyor gibi görünmektedir. Ancak çalışmalarda, olumsuz beklenti ihlali durumunda her zaman kaynak belleği avantajı ortaya çıktığı gösterilmemiştir. Diğer çalışmalarda tam tersine, olumlu beklenti ihlali durumunun kaynak belleği avantajı yaratıyor olduğunu hem davranış tanımlarıyla eşleşen yüzlerin bulunduğu deneylerde (Hechler ve ark. 2016) hem de sosyal işbirliği oyunlarında gösterilmiştir (Bell ve ark. 2012b, Mieth ve ark. 2016). Beklenti ihlali durumunda kaynak belleğinin ne yönde değişeceğine ilişkin alan yazında uyumsuz bilgilerin olması bu konu üzerinde daha fazla çalışma yapılması gerekliliğini ortaya koymaktadır.

Bellek izlerinin zayıf olduğu durumlarda katılımc1lar kaynağı izlerken tahmin yürütme eğilimi gösteriyor gibi görünmektedir. Çalışmaların da gösterdiği gibi sağlam olmayan kaynak bilgisinde kalıp yargılar, kaynak izlemeyi büyük ölçüde etkiyor gibi görünmektedir (Cassidy ve ark. 2012, Kleider ve ark. 2012, Kuhlmann ve ark. 2016). Bu se- 
beple insanlar kaynak bilgisini hatırlayamadıklarında önceki bilgilerine ya da izlenimlerine göre bir yanlılık göstermektedir (örn. Bell ve ark. 2015). Bu açıdan bakıldığında bellek yanlılıklarının ve tahmin etme cevaplarının ayırt edilebildiği bir analiz yönteminin çalışmalarda kullanılması büyük önem taşımaktadır. Sosyal kaynak belleği çalışmalarının büyük çoğunluğunda "Kaynak İzleme için Multinomial Model (Bayen ve ark. 1996)" kullanılmıştır. Bu modelin özellikle kaynak belleği çalışmalarındaki analizlerde, yanlılıkların ayırt edilmesi ve açığa kavuşturulması için tercih edilmesi gerekebilir.

\section{Sonuç}

Kaynak belleğinin temel bilişsel mekanizmasını anlamak özellikle görgü tanıklığı konusuna 1şık tutacaktır. Suç işlediği konusunda şüphelerin olduğu şahıslar hakkında yargılama yapılırken görgü tanıklığına sıklıkla başvurulur. Ancak bu yargılamalarda görgü tanıklığı hatalarına sıklıkla rastlanmaktadır (Safer ve ark. 2016). Bir tanığın suça ilişkin detayları hatırlaması istendiğinde, tanığın suça ilişkin belleği bilinç dışı olarak yeniden yapılanır (Wise ve ark. 2009). Bu yeniden yapılanma sürecinde özellikle kaynak belleğinin hangi faktörlerden etkileniyor olduğu yanlış atıfları önlemek için önemlidir. Bu derleme bu amaçla görgü tanıklığına başvururken dikkat edilmesi gerekenlerle ilgili katkı sunmaktadır. Derlemeye dahil edilen çalışmaların da gösterdiği gibi kaynak belleği beklentiden, tutumdan, duygudan ve kalıp yargıdan etkilenmektedir. Duygu değerliği ve duygusal uyarılmışlık açısından değişimlenen bilgi ve bağlam kaynak belleği üzerinde etkili olmaktadır. Bellek bilgisinin zayıf olduğu durumlarda ise bilginin kaynağını takip edebilmek zorlaşır. Bu gibi bir durumda bilginin kaynağını atfederken kişinin sahip olduğu şemalar, inançlar, beklentiler ve kalıp yargılar daha çok etkili olur. Bu sebeple tanıklar, tanık oldukları olayın detaylarıyla ilgili belleklerindeki boşlukları kendi şemalarıyla, inançlarıyla, beklentileriyle, duygularıyla ve kalıp yargılarıyla dolduruyor olabilirler. Bu sebeple kaynak belleğinin ne tür yanlılıklara daha açık olduğunu araştırmak yanlı̧̧ bilgi atfını önlemek için önemlidir.

\section{Kaynaklar}

Axelrod R (1984) The Evolution of Cooperation. New York, Basic Books.

Balliet D, Parks C, Joireman J (2009) Social value orientation and cooperation in social dilemmas: A meta-analysis. Group Process Intergroup Relat, 12:533-547.

Barrett HC, Kurzban R (2006) Modularity in cognition: framing the debate. Psychol Rev, 113:628-647.

Bayen UJ, Murnane, K, Erdfelder E (1996) Source discrimination, item detection, and multinomial models of source monitoring. J Exp Psychol Learn Mem Cogn, 22:197-215.

Bell R, Buchner A (2010) Valence modulates source memory for faces. Mem Cognit, 38:29-41.

Bell R, Buchner A (2011) Source memory for faces is determined by their emotional evaluation. Emotion, 11:249-261.

Bell R, Buchner A, Erdfelder E, Giang T, Schain C, Riether N (2012a) How specific is source memory for faces of cheaters? Evidence for categorical emotional tagging. J Exp Psychol Learn Mem Cogn, 38:457-472.

Bell R, Buchner A, Kroneisen M, Giang T (2012b) On the flexibility of social source memory: A test of the emotional incongruity hypothesis. J Exp Psychol Learn Mem Cogn, 38:1512-1529.

Bell R, Giang T, Buchner A (2012c) Partial and specific source memory for faces associated to other- and self-relevant negative contexts. Cogn Emot, 26:1036-1055.

Bell R, Mieth L, Buchner A (2015) Appearance-based first impressions and person memory. J Exp Psychol Learn Mem Cogn, 41:456-472. 
Bell R, Mieth L, Buchner A (2017b) Separating conditional and unconditional cooperation in a sequential Prisoner's Dilemma game. PLoS One, 12:e0187952.

Blau PM (1968) Interaction: Social exchange. In International encyclopedia of the social sciences, Vol 7 (Ed DL Sills):452-457. New York, Macmillan/Free Press.

Buchner A, Bell R., Mehl B, Musch J (2009) No enhanced recognition memory, but better source memory for faces of cheaters. Evol Hum Behav, 30:212-224.

Cassidy BS, Zebrowitz LA, Gutchess AH (2012) Appearance-based inferences bias source memory. Mem Cognit, 40:1214-1224.

Chiappe DL, Brown A, Dow B (2004) Cheaters are looked at longer and remember better than cooperators in social exchange situations. Evol Psychol, 2:108-120.

Cook Gl, Marsh RL, Hicks JL (2003) Halo and devil effects demonstrate valenced-based influences on source-monitoring decisions. Conscious Cogn, 12:257-278.

Cosmides L, Tooby J (1992) Cognitive adaptations for social exchange. In The adapted mind (Eds J Barkow, L Cosmides, J Tooby):163-228. New York, Oxford University Press.

Cosmides L, Tooby J (2015) Adaptations for reasoning about social exchange. In The Handbook of Evolutionary Psychology, 2nd ed. (Ed D Buss):625-668. Hoboken, NJ, Wiley.

Doerksen S, Shimamura AP (2001) Source memory enhancement for emotional words. Emotion, 1:5-11.

Duarte A, Henson RN, Graham KS (2011) Stimulus content and the neural correlates of source memory. Brain Res, 1373:110-123.

Durbin KA, Mitchell KJ, Johnson MK (2017) Source memory that encoding was self-referential: the influence of stimulus characteristics. Memory, 25:1191-1200.

Erdfelder E, Kroneisen M (2014) Proximate cognitive mechanisms underlying the survival processing effect. In What is Adaptive About Adaptive Memory? (Eds BL Schwarts, ML Howe, MP Toglia, H Otgaar):160-200. New York, Oxford University Press.

Gallo DA (2010) False memories and fantastic beliefs: 15 years of the DRM illusion. Mem Cognit, 38:833-848.

Genon S, Bahri MA, Collette F, Angel L, D'Argembeau A, Clarys D et al. (2014). Cognitive and neuroimaging evidence of impaired interaction between self and memory in Alzheimer's disease. Cortex, 51:11-24.

Giang T, Bell R, Buchner A (2012) Does facial resemblance enhance cooperation? PLoS One, 7:e47809.

Greenstein M, Franklin N, Klug J (2016) In-group versus out-group source memory: Spontaneously inferred features can both facilitate and impair source memory. Exp Psychol, 63:150-158.

Hamilton WD (1964) The genetical evolution of social behaviour II. J Theor Biol, 7(1):17-52.

Hechler S, Neyer FJ, Kessler T (2016) The infamous among us: Enhanced reputational memory for uncooperative ingroup members. Cognition, 157:1-13.

Johnson MK (1997) Source monitoring and memory distortion. Philos Trans R Soc Lond B Biol Sci., 352:1733-1745.

Johnson MK, Hashtroudi S, Lindsay DS (1993) Source monitoring. Psychol Bull, 114:3-28.

Kensinger EA (2004) Remembering emotional experiences: The contribution of valence and arousal. Rev Neurosci, 15:241-252.

Kensinger EA (2009) How emotion affects older adults' memories for event details. Memory, 17:208-219.

Kleider HM, Cavrak SE, Knuycky LR (2012) Looking like a criminal: Stereotypical black facial features promote face source memory error. Mem Cognit, 40:1200-1213.

Kroneisen M (2017) Is he important to me? Source memory advantage for personally relevant cheaters. Psychon Bull Rev, 25:1129-1137.

Kroneisen M, Woehe L, Rausch LS (2015) Expectancy effects in source memory: How moving to a bad neighborhood can change your memory. Psychon Bull Rev, 22:179-189.

Kuhlmann BG, Bayen UJ, Meuser K, Kornadt AE (2016) The impact of age stereotypes on source monitoring in younger and older adults. Psychol Aging, 31:875-889.

Küppers V, Bayen UJ (2014) Inconsistency effects in source memory and compensatory schema-consistent guessing. Q J Exp Psychol, 67:2042-2059.

Leshikar ED, Duarte A (2012) Medial prefrontal cortex supports source memory accuracy for self-referenced items. Soc Neurosci, 7:126-145.

Mather M, Sutherland MR (2011) Arousal-biased competition in perception and memory. Perspect Psychol Sci, 6:114-133. 
Mattarozzi K, Colonnello V, Russo PM, Todorov A (2018) Person information facilitates memory for face identity. Psychol Res, 83:181-1824.

May CP, Rahhal T, Berry EM, Leighton EA (2005) Aging, source memory, and emotion. Psychol Aging, 20:571-578.

Mealey L, Daood C, Krage M (1996) Enhanced memory for faces of cheaters. Ethol Sociobiol, 17:119-128.

Meyer MM, Bell R, Buchner A (2015) Remembering the snake in the grass: Threat enhances recognition but not source memory. Emotion, 15:721-730.

Mieth L, Bell R, Buchner A (2016a) Cognitive load does not affect the behavioral and cognitive foundations of social cooperation. Front Psychol, 7:1312.

Mieth L, Bell R, Buchner A (2016b) Facial likability and smiling enhance cooperation, but have no direct effect on moralistic punishment. Exp Psychol, 63:263-277.

Mieth L, Buchner A, Bell R (2017) Effects of gender on costly punishment: Gender and punishment. J Behav Decis Mak, 30:899912.

Mitchell KJ, Johnson MK (2000) Source Monitoring: Attributing mental experiences. In The Oxford Handbook of Memory (Eds E Tulving, F (raik):179-195. New York, Oxford University Press.

Mitchell KJ, Johnson MK (2009) Source monitoring 15 years later: What have we learned from fMRI about the neural mechanisms of source memory? Psychol Bull, 135:638-677.

Nairne JS, Pandeirada JNS (2008) Adaptive memory: Remembering with a stone-age brain. Curr Dir Psychol Sci, 17:239-243.

Nairne JS, Thompson SR, Pandeirada JNS (2007) Adaptive memory: Survival processing enhances retention. J Exp Psychol Learn Mem Cogn, 33:263-273.

Nowak MA, Sigmund K ( 2005 ) Evolution of indirect reciprocity. Nature, 437:1291-1298.

Panksepp J, Panksepp JB (2000) The seven sins of evolutionary psychology. Evolution and Cognition, 6:108-131.

Peters J, Koch B, Schwarz M, Daum I (2007) Domain-specific impairment of source memory following a right posterior medial temporal lobe lesion. Hippocampus, 17:505-509.

Reisberg D (2010). Cognition: Exploring the Science of rhe Mind, 4th ed. New York, WW Norton.

Righi S, Gronchi G, Marzi T, Rebai M, Viggiano MP (2015) You are that smiling guy I met at the party! Socially positive signals foster memory for identities and contexts. Acta Psychol (Amst), 159:1-7.

Safer MA, Murphy RP, Wise RA, Bussey L, Millett C, Holfeld B (2016) Educating jurors about eyewitness testimony in criminal cases with circumstantial and forensic evidence. Int J Law Psychiatry. 47:86-92.

Schacter DL (1999) The seven sins of memory: Insights from psychology and cognitive neuroscience. Am Psychol, 54:182-203.

Schaper ML, Mieth L, Bell R (2019) Adaptive memory: Source memory is positively associated with adaptive social decision making. Cognition, 186:7-14.

Suzuki A, Suga S (2010). Enhanced memory for the wolf in sheep's clothing: Facial trustworthiness modulates face-trait associative memory. Cognition, 117:224-229.

Tanyaş H, Mısırlısoy M (2018) Kaynak belleği: Derleme çalışması. DTCF Dergisi, 58:1436-1457.

Tooby J, Cosmides L (1996) Friendship and the banker's paradox: Other pathways to the evolution of adaptations for altruism. Proc Br Acad, 88:119-143.

Trivers R (1971) The evolution of reciprocal altruism. Q R Biol, 46:35-57.

Van Lange PAM, Kuhlman DM (1994) Social value orientations and impressions of partner's honesty and intelligence: A test of the might versus morality effect. J Pers Soc Psychol, 67:126-141.

Van Lange PAM, Otten W, Joireman JA (1997) Development of prosocial, individualistic, and competitive orientations: Theory and preliminary evidence. J Pers Soc Psychol, 73:733-746.

Wise RA, Fishman CS, Safer MA (2009) How to analyze the accuracy of eyewitness testimony in a criminal case. Conn L Rev, 42(2):435-513.

Zappa N (2012) Facial recognition of cheaters and cooperators in group projects. Sentience, 6:22-26. 
Yazarların Katkıları: Yazar çalışmaya önemli bir bilimsel katkı sağladığııı ve makalenin hazırlanmasında veya gözden geçirilmesinde yardımcı olduğunu kabul etmiştir.

Danışman Değerlendirmesi: Dış bağımsız

Çıkar Çatışması: Yazar çıkar çatışması bildirmemiştir.

Finansal Destek: Yazar bu çalışma için finansal destek almadığııı beyan etmiştir.

Authors Contributions: The author attest that she has made an important scientific contribution to the study and has assisted with the drafting or revising of the manuscript.

Peer-review: Externally peer-reviewed.

Conflict of Interest: No conflict of interest was declared by the author.

Financial Disclosure: The author declared that this study has received no financial support. 